\title{
A REVIEW ON PARTIAL INFILLED FRAMES UNDER LATERAL LOADS
}

\author{
${ }^{1}$ P. M. Pradhan ${ }^{*},{ }^{2}$ P. L. Pradhan, ${ }^{1}$ R. K. Maskey \\ ${ }^{1}$ Department of Civil \& Geomatics Engineering, Kathmandu University, Dhulikhel, Nepal \\ ${ }^{2}$ Department of Civil Engineering, Institute of Engineering, Tribhuvan University, Nepal \\ *Corresponding address: prachand@ku.edu.np \\ Received 25 July, 2011; Revised 02 January, 2012
}

\begin{abstract}
Masonry infilled walls are provided within the reinforced concrete structures without being analyzed as a combination of concrete and brick elements, though in reality they act as a single unit during earthquakes. The performance of such structures during earthquakes has proved to be superior in comparison to the bare frames in terms of stiffness, strength and energy dissipation. There are plenty of researches done so far for infilled frames, however partially infilled frames are still the topic of interest. Though it has been understood that the infills play significant role in enhancing the lateral stiffness of complete structure, the past experience in various earthquakes have proved that the partially infilled framed structures somehow are affected adversely. This paper intends to highlight the need of knowledge on partially infilled frames and the composite action. It also summarizes the findings till date done by various researchers on the behavior of partial infilled frames under lateral loads.
\end{abstract}

Key words: Partial infill, captive columns, lateral load

\section{INTRODUCTION}

It is a general practice in Nepal and other developing countries to provide brick masonry infill walls within the columns and beam of Reinforced concrete frame structures. Such composite structures formed by the combination of a moment resisting plane frame and infill walls is termed as "infilled frames". Infill walls provide durable and economical partitions having relatively excellent thermal and sound insulation with high fire resistance. In the areas where the burnt clay bricks are easily available, these infills are made in brick masonry and in other areas, hollow or solid concrete blocks are used. Infill walls are usually provided for functional and architectural reasons and they are normally considered as non-structural elements and their strength and stiffness contributions are ignored in the analysis works despite significant advances in computer technology and availability of modern computational resources. The reasons for ignoring their presence may be due to the complication involved in analysis and also the uncertainty about the non-integral action between infill and the frame. Thus, the analyses of structures are being based on the frames.

When subjected to gravity loads only, the infill walls only add their self weight. However, an infill wall tends to interact with the frame when subjected to seismic forces. The performance of structures can be greatly improved by the increase in strength arising from the nonstructural components; on the contrary, this increase in strength also accompanies an increase in initial stiffness of the structure, which may consequently attract additional seismically induced lateral inertia forces [1]. An infill wall also exhibits energy dissipation characteristics under earthquake loading as the frame members compress the infills at some locations. The infill walls when compressed carry a part of the load by providing strut action to the frame. As such, the infill walls contribute as a surplus benefit during the times of earthquakes.

Generally, all parts of the frame may not include infills as they are provided as per the functional and architectural needs. It has been observed from past earthquakes that the infills contribute in the enhancement of overall lateral stiffness of the structure. Strong infills have often prevented collapse of relatively flexible and weak reinforced concrete frames. Brick 
masonry, in cement mortar, exhibits highly non-homogeneous behavior due to relatively weak shear strength of mortar and sometimes due to weak compressive strength of bricks. The behavior of reinforced concrete frames with brick masonry infills depend upon the composite action of the frame and the infill. The structural response is quite complex as it involves an interaction of infill behavior, reinforced concrete frames behavior and length of contact between infill and frame.

\section{TYPES OF INFILL PROVISIONS}

Infills are provided fully or with openings as per the needs for provisions of partitions or for doors and windows. The four different general types of frames are shown in the figures below; bare frame (Fig.1), fully infilled frame (Fig.2), infilled frame with opening (Fig.3) and partial infilled frame (Fig.4).

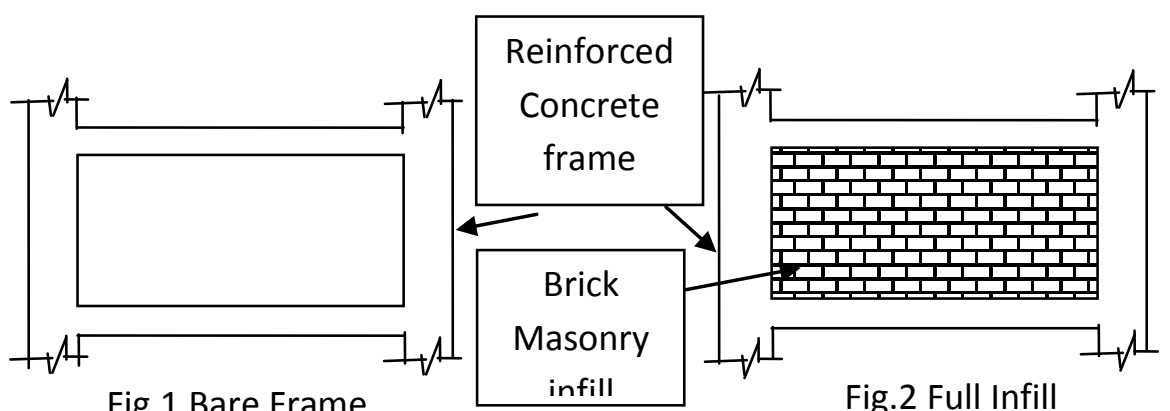

Fig.1 Bare Frame

Fig.2 Full Infill

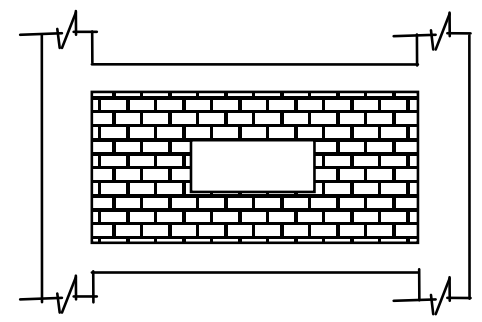

Fig.3 Infill with opening

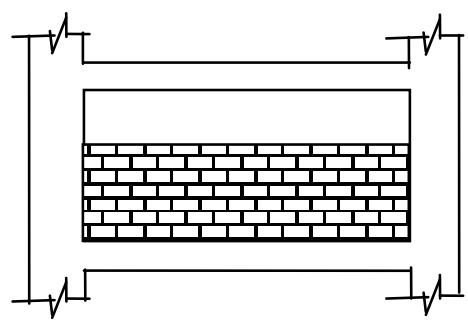

Fig.4 Partial Infill frame

\section{PARTIALLY INFILLED FRAMES}

In majority of hospitals, academic institutions and commercial complexes, partial infills are provided to attain light within the rooms. It is observed that such walls on one hand contribute in enhancing the lateral stiffness of the structure while on the other hand they play ironic role with an adverse effect called "short column effect". The prevailing scenario of structures constructed with partial infills in Nepal is shown here (Fig.5). 

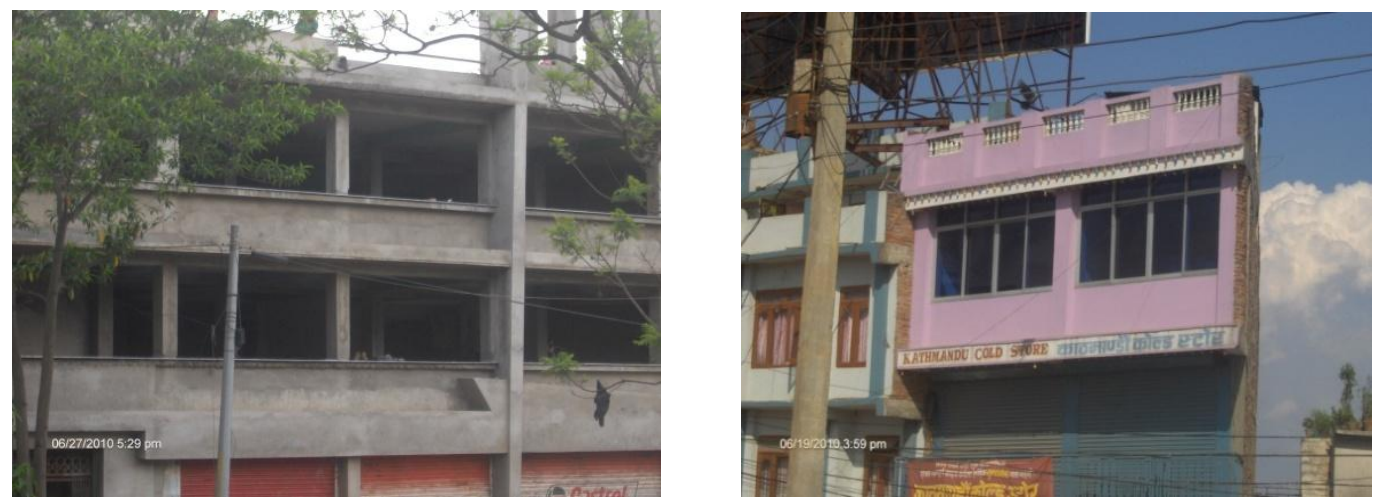

Fig. 5: Partial Infilled structures

The term short column effect is defined as the effect caused to the full storey slender column whose clear height is reduced by its part height contact with a relatively stiff non-structural elements such as a masonry infill, which constrains its lateral deformation over the height of contact. The column which gets its effective height reduced due to such partial infill walls is termed captive column, or in general, the short column. The shear required to develop flexural yield in the effectively shortened column is substantially higher than shear required developing in full length column [2]. If the designer has not considered the short column effect, shear failure may occur before flexural yield and often fail in brittle manner. The cracking in captive column generally initiates from window headers and sill level. The short column effect arises mostly due to accidental modification to the original structural configuration by restricting its freedom to deform laterally due to the presence of nonstructural elements that partially confine it. The non structural elements keep some portion of the column captive and only the free portion of the column can deform laterally.

From the available earthquake damage reports, with few exceptions worldwide, numerous cases of captive column have occurred. The direct visual effect is on the column itself however, the cause usually is due to the non-structural elements which impose the pattern of response to the earthquake motions different from the expected behavior of the column itself without the non structural elements. Few damages due to short column effect on building structures are shown in the following photographs (Fig. 6 and 7). The need to study on short column effect for lateral loading may also be justified by observing the photographs.

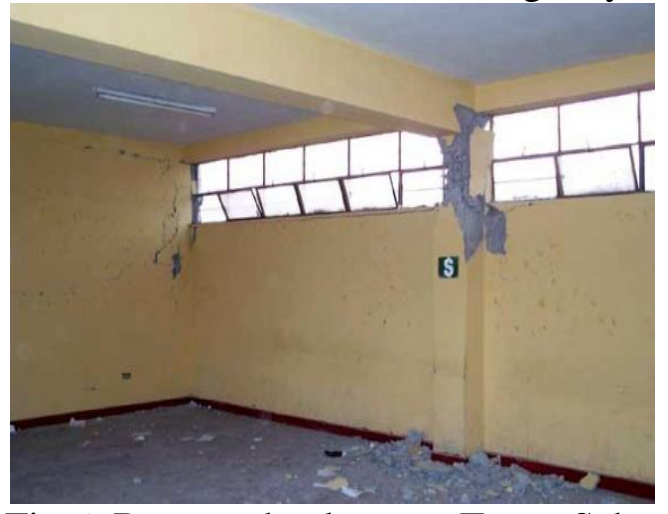

Fig 6: Damaged column at Tacna School,

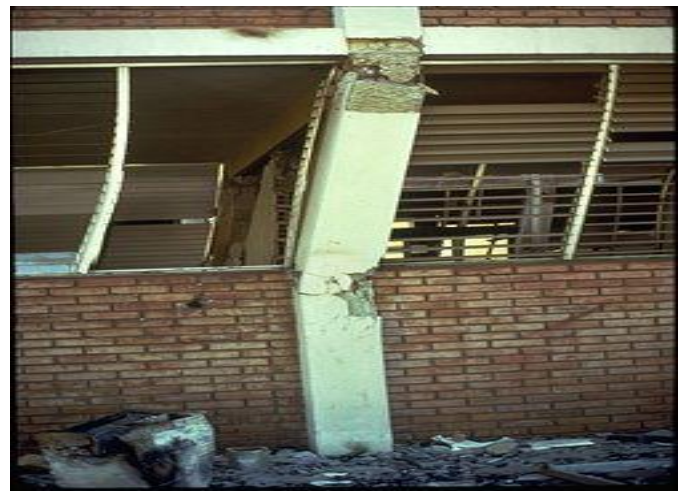

Fig.7: Captive column failure: (Source: June 23, 2001 Peruvian Earthquake); (source:peer.berkeley.edu/..html, 2010)

When the floor slab moves horizontally during an earthquake, the upper ends of these columns undergo the same displacement. However, the stiff walls restrict the horizontal movement of the lower portion of a short column and get deformed by the full amount over 
the short height adjacent to the window opening. The regular columns get deformed over the full height. Since the effective height over which a short column can freely bend is small, it offers more resistance to horizontal motion and thereby attracts a larger force as compared to the regular column. As a result, the short column sustains more damage. Such problems originate in the architectural designs of most of the buildings. Contractors often add partial height walls between columns at the request of the building owners (after the building is occupied), without taking any consent of the involved architect or engineer. Thus, the designers and contractors should understand the problem to avoid short column effect.

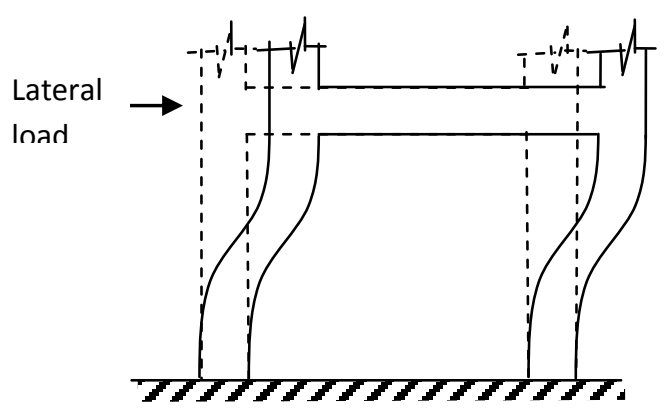

Fig.8: Lateral deformation in bare frame

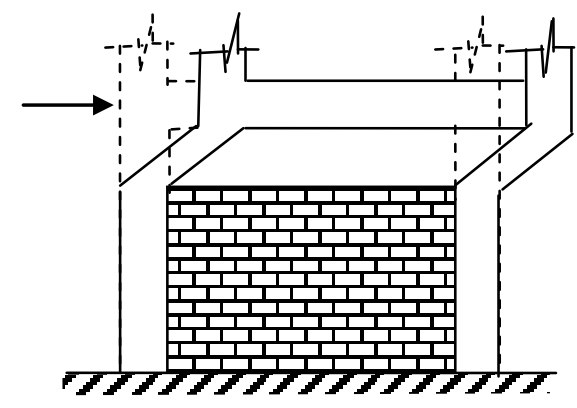

Fig.9: Lateral deformation in partial infilled frame

The Burdur earthquake (Turkey) of May 12, 1971, although only of moderate-sized magnitude, was responsible for much loss of life and property damage. The presence of fullheight and/or partial-height infill walls in some reinforced concrete-framed structures completely altered the behavior of the frame elements. Damage to a four-story, reinforced concrete school building has been described, as a typical example of this kind of failure [3].

Partial infills are provided in some of the cases like high narrow windows on tall window sills; where openings are provided at the top level of the panel for lighting and ventilation generally in institutional class rooms, store rooms, doctor's consulting rooms (hospitals) and so on, thereby restricting the visibility from one space to the other which is the desired function for the user. Similarly, numerous structures built during the 1950's in different countries are observed to have corridors left open to the façade. Transparent light handrails, heavy and stiff partial height parapets were used to avoid electric lightings. Most of the buildings of such kind have failed in the past earthquakes [4]. Partially buried basements are provided up to street level with only a small portion of the height of the column continuing up to the storey slab. Such openings provide ventilation and natural lighting to the basements. When buildings rest on sloping ground, due to the rigid floor diaphragm action during the earthquake shaking, all columns move horizontally by the same amount along the floor slab at a particular level. If short and tall columns exist within the same storey level, the short columns attract large earthquake force and thus get damaged more relative to the tall columns. The short column effect also occurs in columns that support mezzanine floors.

\section{DISTINCTION BETWEEN CAPTIVE COLUMN AND SHORT COLUMN}

Although the terms captive column and short column are used interchangeably in literatures, the reasons that cause them are completely different. Captive column is affected by the presence of adjoining non-structural elements (like infill) where as the short column effect is the case when the column height is made shorter than the neighboring columns by horizontal structural elements, like beams, girders, stairways landing slabs, ramps that frame at the mid height of the column. Short column effect may also occur at the column just above the foundation level where openings are kept for sanitary or mechanical reasons. 


\section{MATHEMATICAL EXPLANATION OF CAPTIVE COLUMN EFFECT}

A simple explanation to show how the shear force in the short column would increase drastically may be illustrated from the general static equilibrium method. If we consider responses $\mathrm{V}$ as the shear force and $\mathrm{M}_{\mathrm{T}}$ and $\mathrm{M}_{\mathrm{B}}$ as the bending moments after analyzing a frame structure which is acted upon by a gravity load, without consideration of infill wall, then taking a column of length $L$, the total shear force $V$ shall be equal to $\left(M_{T}+M_{B}\right) / L$ from static equilibrium equation. However, if the partial height of infill wall is $L^{\prime}$, then the new shear force $V^{\prime}$ would be $\left(M_{T}+M_{M}\right) / L$ '.

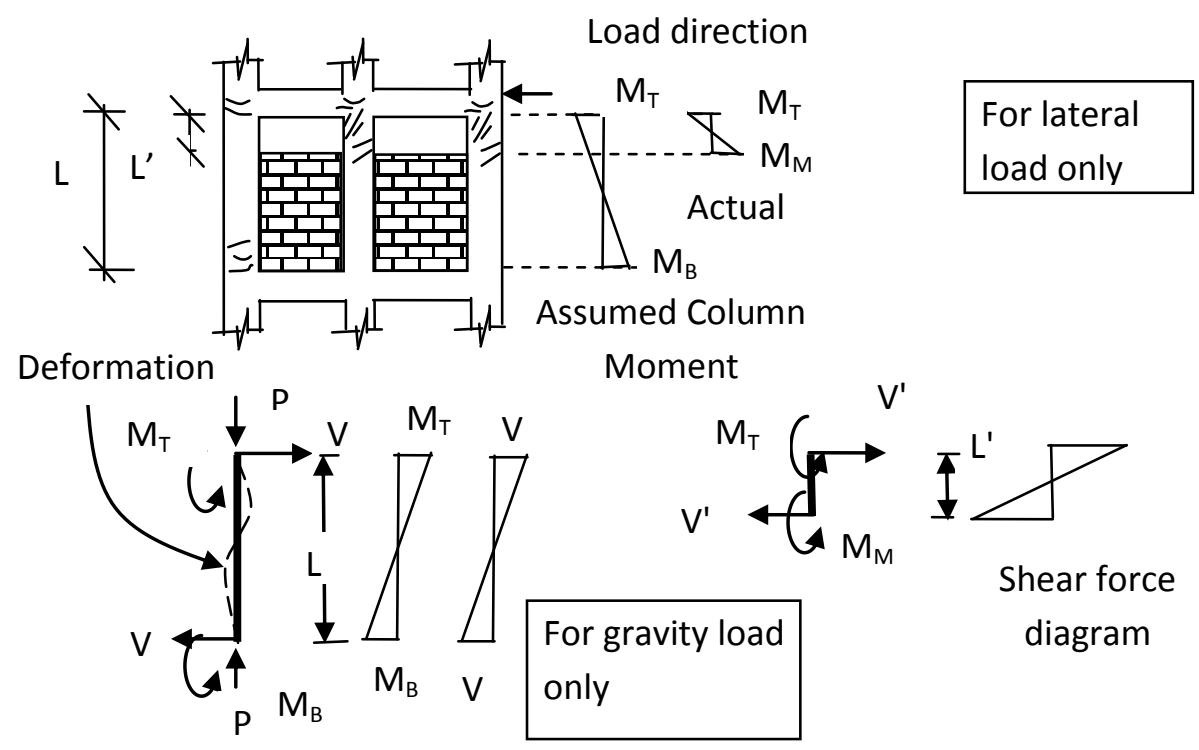

Fig.10: Captive column with moment and shear increment

Thus, $\begin{aligned} \mathrm{V} & =\left(\mathrm{M}_{\mathrm{T}}+\mathrm{M}_{\mathrm{B}}\right) / \mathrm{L}=\Sigma \mathrm{M} 1 / \mathrm{L} \\ \mathrm{V}^{\prime} & =\left(\mathrm{M}_{\mathrm{T}}+\mathrm{M}_{\mathrm{M}}\right) / \mathrm{L}^{\prime}=\Sigma \mathrm{M} 2 / \mathrm{L}^{\prime}\end{aligned}$

But $\Sigma \mathrm{M} 1=\Sigma \mathrm{M} 2$, therefore, $\Sigma \mathrm{M} 1=\mathrm{V} \times \mathrm{L}$

$$
\text { And } \Sigma \mathrm{M} 2=\mathrm{V}^{\prime} \times \mathrm{L}^{\prime}
$$

Say $\mathrm{L}^{\prime}=\mathrm{L} / 4$, then, $\quad \Sigma \mathrm{M} 2=\mathrm{V}^{\prime} \times \mathrm{L} / 4$

Thus, $\mathrm{V}^{\prime}=4 \Sigma \mathrm{M} 1 / \mathrm{L}$

Divide equation (1) by (4), $V / \mathrm{V}^{\prime}=1 / 4$, thus, $\mathrm{V}^{\prime}=4 \mathrm{~V}$

The above equation shows that the shear force on the short column is increased 4 times when the gap of $1 / 4^{\text {th }}$ of the total length of column is left unfilled. The shear force is corresponding to the gravity load only and so it will not be of great significance and there is no P- $\Delta$ effect considered. Thus, though significant shear is increased during normal gravity load condition, the structures sustain the effect of short column without any damage. This significant shear increment will be within the limits of shear capacity of the columns, so damage is not possible.

If we specifically consider a laterally loaded frame's deformation, we may observe the column deforms as shown (Fig.11). The total deformation in the column is due to the deformation due to gravity loads and deformation due to storey drift. The storey drift is a function of the stiffness of the story and the structure, the geometry of the frame, the mass of the structure and the ground motion. The captive columns are less affected when the loading 
is only gravitational, as the flexural moments in columns are small, but in the case of lateral load, the captive columns experience large flexural moments and as such the response is large deflection, mainly because they are controlled by the storey drift. The presence of partial infill wall again resists the columns and the large shear force effect on the column would lead to failure of the column at the open portions. Thus, the short column effect suggests an adverse effect to the structures if they are not analyzed before hand for lateral loads. There is a need of providing measures to incorporate the short column effect in the model so as to design safe structure against brittle shear failure.

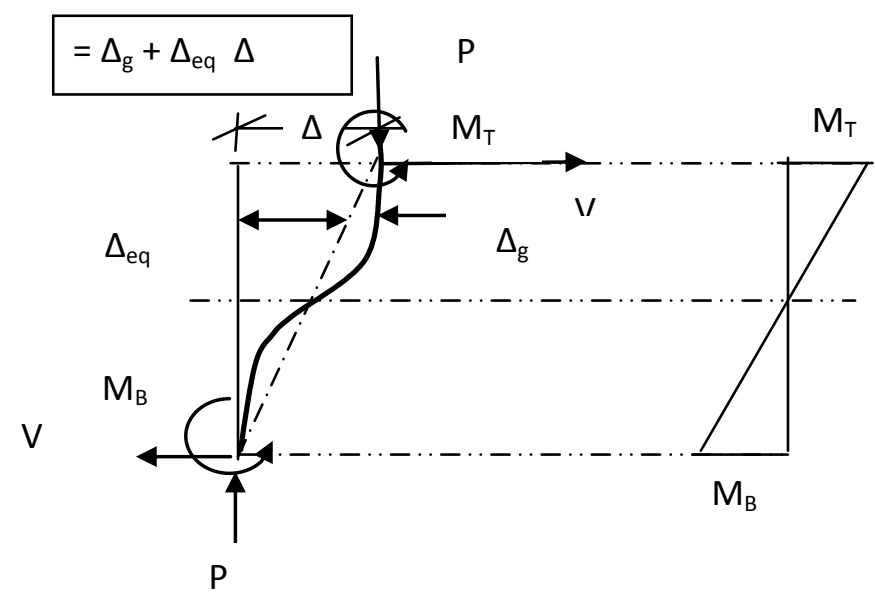

Fig.11: Internal forces in columns and the deformations and moments due to combination of gravity and lateral loads [4]

Thus, on one hand the infill would suggest benefit for structures against lateral forces while on the other hand if provided partially, adverse effect may prevail. As the loading in structure during earthquake is cyclic, it becomes important to study the effect on the structures under dynamic loading for better accuracy. Therefore, the need of understanding the composite action of partial infill wall on reinforced concrete frame structures under dynamic loading is very important for seismic loadings.

\section{IN PLANE ACTION}

The infills contribute in stiffening of the frame and it is reported that the infills can increase the stiffness of the frame 4 to 20 times (referring to number of literatures). The in-plane action of the infill varies with the level of lateral load applied on the frame. The infill remains in contact with the frames at very low lateral loads and as such there is composite action between the frame and infill and thus the stiffness of the system is too large. With the increase in load, the infills start cracking at the frame-infill interface. With further increase in lateral load, the separation between frame and infill takes place at the locations where there is tension. The locations where the infill gets compressed, there forms a diagonal strut action. Due to this, the system behaves as a braced frame or truss. The failure modes for such a system may be of the following three types:

i) When the column's stiffness is relatively stronger than that of the infill, the compression strut cracks due to diagonal tension or shear or it gets crushed under compressive force applied by the bracing action. The stiffness start degrading as the lateral loading is increased. With the further increase in lateral load, the masonry infill fails and the load is transferred in the two actions, whence the columns fail in flexure or in shear. 
ii) In case the infill is stronger than the columns, the columns fail in shear due to eccentric strut action of the infill.

iii) The infill may also fail in shear along a bed joint whence the formation of shear crack separates the panel into two parts almost of equal heights and effective length of the column is reduced to half. The system will then behave like a knee braced system and the failure mechanism is governed by either flexural or shear capacity of the column. Accordingly, either sudden collapse due to shear failure of column or a relatively ductile flexural failure of column may occur.

The infill walls face both in plane as well as out-of-plane forces during earthquake and they resist the forces adding up surplus stiffness to the frames. In this paper, the literatures on experimental and analytical studies, basically on the in-plane behavior of masonry infill walls under both static and dynamic loadings have been reviewed.

The behavior of multi storey infilled frames under lateral load is essentially that of a vertical cantilever [5]. The wall tends to increase the stiffness and also alter the mode of response of the frame changing it to a shear wall and as a result changing the entire structure and the resulting distribution of forces among the different frame components. The stiffening effect of the infill panel on the frame is normally represented by a diagonal strut having same thickness as the panel and an effective width depends on a number of factors like the relative stiffness of columns and the infill, the height to length ratio of infill, the stress-strain relationship of infill material and the diagonal load on the infill. Normally, the effective width of strut increases with the increase in column stiffness and panel height to length ratio, and decreases with the increasing value of the load and modulus of elasticity of the infill material.

\section{LITERATURE REVIEW Infilled frames}

Thomas and Ockleston were one of the early major contributors in connection to the interaction between wall and frame [6]. Polyakov started his research on "Masonry in Framed Buildings" in 1956. During the 1950s initial efforts were made for analytical modeling of infilled frames and at the beginning the infill panels were replaced by vertical cantilevers having equivalent shear and flexural properties. It was assumed that when an infilled frame is subjected to lateral loads, the transfer of load takes place through a truss action in the infill and this led to the development of diagonal strut model. The strut action takes place when infill along the unloaded diagonal gets separated from the beams and columns due to flexural deformation of adjoining frame members and a strut action is formed along the compressed infill diagonal [7]. Polyakov [8] suggested the possibility of considering the effect of infill in each panel as equivalent to diagonal bracing and this suggestion was later taken by Holmes [9].

Homes [9] studied experimentally on steel frames infilled with brick masonry and reinforced concrete walls and developed semi-empirical design method for laterally loaded infilled frames based on equivalent strut concept. His tests suggested that reinforced concrete walls increase the strength of frame by $400 \%$ whereas the brick masonry infills increase around $100 \%$. He indicated that the presence of vertical load increased the strength by about $15 \%$ and that openings in walls might reduce strength up to $40 \%$ based on the composite behavior. The infill was considered to fail in compression. The load carried by infill at failure was calculated by multiplying the compressive strength of material by the area of equivalent strut. He states that the width of equivalent strut to be one third of the diagonal length of infill, which resulted in the infill strength being independent of frame stiffness. The load carried by 
the frame was then calculated by assuming that the strut was shortened by an amount which was its length multiplied by the strain at failure in the infill material. Subsequently, many investigators developed the strut width value related to the length of contact between wall and the columns and between the wall and the beams.

As per Agarwal and Shrikhande [2] the proposed range of contact length is between onefourth and one-tenth of the length of panel. There have been a lot of research works related to infilled framed structures with micro and macro modeling. Most of the researchers have adopted single and some have adopted multiple struts in their studies. Smith [10] has so far been found the pioneer in the use of single strut to represent the masonry infill.

Mainstone [11] has given equivalent diagonal strut concept by performing tests on model frames with brick infills. His approach estimates the infill contribution both to the stiffness of the frame and to its ultimate strength. The strut width expression according to him is: Strut width, $w=0.175 \mathrm{D}\left(\lambda_{1} \mathrm{H}\right)^{-0.4}$ where $\mathrm{D}$ is the diagonal length of the infill. The expression $\lambda_{1} \mathrm{H}$ $=\mathrm{H}\left[\mathrm{E}_{\mathrm{m}} \mathrm{t} \operatorname{Sin} 2 \theta / 4 \mathrm{E}_{\mathrm{c}} \mathrm{I}_{\mathrm{c}} \mathrm{h}_{\mathrm{m}}\right]^{1 / 4}$, where $\mathrm{H}$ is the height of the frame, $\theta$ is the angle made by the strut with the horizontal, $\mathrm{E}_{\mathrm{c}}$ and $\mathrm{I}_{\mathrm{c}}$ are the Young's modulus and Moment of inertia of column respectively and $E_{m}, t$ and $h_{m}$ are the Young's modulus, thickness and height of masonry infill respectively. Later, Klingner and Berter [12], Liauw and Kwan [13], Pauley and Priestly [14], Crisafulli [15], Tomazevic [16] etc. have put their efforts in researches towards the infilled framed structures.

Liauw and Kwan [13] studied experimentally and analytically the behavior of non-integral infilled frames. Finite Element method was adopted to find the effects of nonlinearities of the material and the structural interface, the initial lack of fit and friction at the interface was considered. They have given the expression for strut width as $w=0.95 h_{m} \operatorname{Cos} \theta / \sqrt{ }\left(\lambda h_{m}\right)$, where $\left.\lambda=E_{m} t \operatorname{Sin} 2 \theta / 4 E_{c} I_{c} h_{m}\right]^{1 / 4}, h_{m}$ is the height of masonry, $\theta$ is the angle subtended by the diagonal strut with the horizontal, $\mathrm{E}_{\mathrm{m}}$ and $\mathrm{E}_{\mathrm{c}}$ are the Young's modulus of elasticity of masonry and concrete materials, $t$ is the thickness of masonry panel and $I_{c}$ is the moment of inertia of concrete columns.

Paulay and Preistly [14] gave the width of diagonal strut at the 0.25 times the diagonal length of the strut and many other researchers also have come up with somewhat near about results for the same. The horizontal shear provided by the infill is given by the relation; $V_{f}=\tau_{0} L_{m} t+$ $\mu R_{s} \operatorname{Sin} \theta$ where, $L_{m}$ is the length of masonry wall, $R_{s}$ is the resultant force offered by the diagonal strut, $\theta$ is the angle subtended by the strut with the horizontal and $\mu$ is the frictional coefficient.

Hendry [17] proposed the effective strut width expression as $\mathrm{w}=0.5\left[\alpha_{\mathrm{h}}+\alpha_{\mathrm{L}}\right]^{1 / 2}$, where the $\alpha_{\mathrm{h}}$ and $\alpha_{\mathrm{L}}$ are the contact length between wall and column and beam respectively at the time of initial failure of wall.

$$
\alpha_{\mathrm{h}}=\pi / 2\left[\mathrm{E}_{\mathrm{c}} \mathrm{I}_{\mathrm{c}} \mathrm{h}_{\mathrm{m}} / 2 \mathrm{E}_{\mathrm{m}} \mathrm{t} \sin 2 \theta\right]^{1 / 4} \text { and } \alpha_{\mathrm{L}}=\pi\left[\mathrm{E}_{\mathrm{c}} \mathrm{I}_{\mathrm{b}} \mathrm{L} / 2 \mathrm{E}_{\mathrm{m}} \mathrm{t} \sin 2 \theta\right]^{1 / 4}
$$

In addition to these studies, large number of researches have been done in the past for fully infilled frames with and with out openings.

\section{Partially infilled frames; review}

Very few literatures are available regarding partial masonry infilled framed structures so far. Paulay and Priestley [14], state that the partial infill wall stiffens the frame, reduces the natural period and increases seismic forces. According to them, if the frame is designed for ductile response to design level earthquake, without considering the effect of the infill, plastic 
hinges might be expected at the top and bottom of columns or preferably in beams at the column faces. These hinges could develop at a fraction of the full design level earthquake.

If there are three columns (two bays) the influence of infill will be to inhibit beam hinges and stiffen the center and the column at the windward side, causing plastic hinges to form at the top of the column and top of the infill. The column shears would increase significantly. The actual column moment is also seen to be increased in the partial infilled frame compared to the assumed column moment.

Huang et al. [18] have tested six reinforced concrete frames with or without masonry infill (including partial infilled) under horizontal cyclic loads. They have compared their work with Chen's [19] research for verification.

Taher and Afefy [20] have done investigation on infill (including partial infill) in the seismic resistance of reinforced concrete structures. The studies for various percentage openings are performed. The most simplified equivalent frame system is considered to handle multistory multi-bay infilled frames. The system consists of homogeneous continuum for the reinforced concrete members braced with unilateral diagonal struts for each bay, which activate only in compression. The effect of number of storeys, number of bays, infill proportioning and infill locations are investigated. Geometric and material nonlinearity of both infill panel and reinforced concrete frame are considered in the nonlinear finite element analysis. The results reflect the significance of infill in increasing the strength, stiffness, and frequency of the entire system depending on the position and amount of infilling. Lower infilling is noted to provide more stiffness for the system as compared with upper locations.

Ghassan [21] has dealt for partial infills using Mainstone's [11] expression of strut width and modified with reduction factors. In a partial infilled frame, the shortened column length shall be equal to the unbraced opening length for the windward column, while the length for the Leeward column remains as it is. Pradhan [22] studied on the influence of infilled wall on reinforced concrete frames and states that when infilled frames are laterally loaded the first crack in the infilled frames appears at about $1 / 3^{\text {rd }}$ of the ultimate load when there is no opening and about $1 / 2$ of the ultimate load when there are large openings. He further states that the length of contact is about $1 / 3^{\text {rd }}$ of the column height at the top of column and about $1 / 6^{\text {th }}$ of the length of beam on either side of it. From his modified strut models he concludes that beyond $40 \%$ of opening in infill wall, the stiffness is about $1 / 4^{\text {th }}$ of the fully infilled frame. Cracks appear at the corners of openings and they need to be strengthened initially.

Subramanian and Jayaguru [23] have conducted study on behavior of partial infilled reinforced concrete frames with masonry infills. Experimental investigations were done on partially infilled $1 / 3$ scale model reinforced concrete frames with and without masonry units under lateral loading. The partially infilled masonry wall induced captive column effect and leads to a severe failure of the column, on the other hand, the masonry inserts over the partial infill stiffness of structure by forming a compression strut thereby avoiding critical captive column damage. The results demonstrate the failure with respect to strength, stiffness, ductility and hysteretic characteristics.

\section{CONCLUSION}

It is observed from the various research works that there is no doubt that the infill walls contribute in enhancing the structural strength. However, the contribution of partial infill walls must be well identified so that while analyzing models for real structures, the composite 
action of the frame and infill would be realized. The lessons from the past earthquakes also indicate that partial infilled frame structures are vulnerable to ground motions and if there is a method identified to model such structures, the earthquake hazard to structure would be reduced significantly.

When it is not possible to avoid short columns, this effect must be considered either in the analysis or during the design of column member. From the knowledge that there would be significant increase in shear in the case of captive column the Indian Standard IS:139201993, for ductile detailing of RC structures, requires special confining reinforcement to be provided over the full height of columns that are likely to sustain short column effect. The special confining reinforcement (i.e., closely spaced closed lateral ties) must extend beyond the short column into the column vertically above and below by a certain distance. So far, exact scenario regarding analysis for captive columns is yet to be understood for précised responses on shear and bending and the convenient modeling method is also not postulated for such structures. More researches need to be done, and in fact by experimentation the validation would be better quantified.

\section{REFERENCES}

[1] Slu, R K L, Chandler A M, Sheikh, M N \& Lam N T K, Influence of non-structural components on lateral stiffness of tall buildings, The Structural Design of Tall and Special Buildings, 14(2) (2005)143.

[2] Agarwal, P \& Shrikhande M, Earthquake Resistant Design of Structures, Prentice Hall of India Pvt. Ltd., India, (2006).

[3] Uzsoy, S Z \& Citipitioglu, E, Influence of infill walls on building frames: An example from the May 12, 1971 earthquake in Turkey", Bulletin of the seismological Society of America, Seismological Society of America,62(5)(1972) 1113.

[4] Guevara, LT \& Garcia, LE, The captive and short column effects, Earthquake Spectra, 21(1) (2005) 141.

[5] Fintel, M, Multistory Structures, Handbook of Concrete Engineering, Chapter 10, CBS Publishers, (1986) 357, ISBN 81-239-0843-1.

[6] Sahlin, S, Structural Masonry, Prentice Hall, Inc. Eaglewood Cliffs, New Jersey, USA, (1971).

[7] Polyakov, S V, Masonry in framed buildings, Gosudalst-Vennoe'stvo Literature po Straitel' stuv i Arkitecture, Moskva, Trans. G.L. Cairns, Building Research Station, Watfor, Herts, (1956).

[8] Polyakov, SV, On the Interaction between masonry filler walls and enclosing frame when loading in the plane of the wall, Translation in Earthquake Engineering, Earthquake Engineering Research Institute, San Francisco, (1960) 36.

[9] Holmes, M, Steel frames with brickwork and concrete infilling, Proceedings of the Institution of Civil Engineers, 19 (1961) 473.

[10] Smith, B S, Lateral stiffness of infilled frames, Journal of the Structural Division, ASCE, 88 (1962) 183. 
[11] Mainstone, R J, On the stiffnesses and strengths of infilled frames, Proceedings of the Institution of Civil Engineers, Supplement (V), (1971)57.

[12] Klingner, R \& Berter, V, Earthquake resistance of infilled frames, ASCE Journal of the Structural Division, 100 (1978) 973.

[13] Liauw, T C \& Kwan, K, Non-linear behavior of non-Integral infilled frames, Computers and Structures, 18 (1984) 551.

[14] Pauley, T \& Priestley, M J N, Seismic design of concrete and masonry buildings, John Wiley and Sons Inc., New York, 1992.

[15] Crisafulli, F, Seismic Behavior of Reinforced Structures with Reinforced Masonry Infills, Ph. D. thesis, University of Canterbury, New Zealand, 1997.

[16] Tomazevic, M, Earthquake Resistant Design of Masonry Buildings, Imperial College Press, London, Great Britain, 1999.

[17] Hendry, AW, Structural Masonry $2^{\text {nd }}$ Ed., MacMillan Press, London, (1998).

[18] Huang, C H, Tuan Y A \& Hsu, R Y, Nonlinear pushover analysis of frames, Earthquake Engineering and Engineering Vibration, 5(2) Article ID; 1671-3664 020245-11, (2006).

[19] Chen, Yi-Hsin, Seismic Evaluation of RC Buildings infilled with Brick Walls, Ph.D. Thesis, National Cheng Kung University, Tainan, Taiwan,2003.

[20] Taher, S. El-Din \& Afefy, H.M. El-Din, "Role of masonry infill in seismic resistance in RC structures", The Arabian Journal for Science and Engineering, 33(2B) (2008).

[21] Ghassan Al-Chaar, Evaluating strength and stiffness of unreinforced masonry infill structures, Construction Engineering Research Laboratory, US Army Corps of Engineers, ERDC/CERL TR-02-1(2002).

[22] Pradhan, P L, Composite Actions of Brick Infill Wall in RC Frame under In-Plane Lateral Load, Ph.D. Thesis, Department of Civil Engineering, IOE, Tribhuvan University, 2009.

[23] Subramanian, K \& Jayaguru, C, Lateral behavior of partially infilled reinforced concrete frames with masonry inserts", African Journal On Line (AJOL), Journal of Civil Engineering Research and Practice, ISSN: 1729-5769,6(2) (2009). 